\title{
Exploring Educational Change in First-Year Calculus: A Comparative Case Study ${ }^{1}$
}

\author{
Vidar Gynnild, Department of Education and Lifelong Learning (IPL), Norwegian University of \\ Science and Technology (NTNU)
}

\begin{abstract}
This article draws on research conducted in a mandatory, first-year calculus course at the Norwegian University of Science and Technology. By the turn of the century concerns were expressed over high failure rates in calculus, and action was called for to remedy the situation. In the years to come, various measures were introduced, though rather scattered and unsystematic. From 2013 onwards development initiatives in the course became more systematic, ensued by expectations of improved learning outcomes. This study draws on data collected by identical surveys conducted four years apart with a view to similarities and differences in attitudes and behaviours. Contrary to expectations, observed changes turned out to be marginal, if not totally missing, which in turn motivated the search for explanations to design more productive strategies.
\end{abstract}

Keywords: Assessment; attitudes; behaviours; calculus; educational change

\section{BACKGROUND AND RESEARCH PROBLEMS}

First-year calculus is an entry point to studies in engineering education, and as such a worthwhile topic for educational research and development. Students often struggle to pass this "hurdle", and professors continuously strive to improve existing learning environments to help them cope with typical barriers and unwanted study behaviours. Examples include rote, manipulative learning and instrumental learning strategies, and the literature reports on a spectrum of concepts causing problems (White \& Mitchelmore, 1996). Calculus learning is often characterized by memorization of symbols and procedures rather than construction of meaning, and students often lack an ability to reason from basic principles (Heid, 1988).

At NTNU, calculus is one of four mandatory courses in the first year with an estimated workload of 7.5 credits, adding up to a total of 30 credits the first semester. Even though calculus students are among the best in High School, transitions to university can be challenging in several different ways. Workloads and progression typically exceed prior experiences, while students at the same time must adapt to new social environments outside residential cities, often located far away from their respective families.

Learning outcomes in calculus include the recognition and application of concepts, results and methods for single variable analysis, including limits, continuity, differentiation and integration. Students should also be able to apply numerical methods for solution of non-linear equations and integrations.

Historically, teaching featured lectures and weekly exercises, and the approval of a certain number of submissions was required to sit the exam. In theory, this may sound ideal for motivated and hardworking students; however, attitudes and behaviours differed widely, some resorting to instrumental behaviours aimed at acquiring minimum pass requirements. Similar observations were made by Benson Snyder 50 years ago in his seminal book on college learning (Snyder, 1971). To account for his observations, this researcher theorized the existence of two curricula - the "open" and the "hidden", and Snyder believed students might not even be aware of the disjunction between them.

In this paper, an "attitude" is defined as the ability and willingness to learn, and as such may be subject to change by appropriately designed learning interventions. "Study behaviour" is used as a superordinate concept encompassing both attitudes and study habits. A premise is that the complex interplay between learning environments and students may result in diverse processes and outcomes. Focus is here on the

\footnotetext{
${ }^{1}$ This is an abbreviated and redrafted version of: Gynnild, V., \& Tyssedal, J. S. (2020), Can students' attitudes and behaviors be changed by educational interventions? A comparative case study. Dansk Universitetspaedagogisk Tidsskrift (DUT), Vol. 16, No. 29, pp. 14-33. Retrieved from https://tidsskrift.dk/dut
} 
study of educational change and causality: Did students' attitudes and study behaviours change as a result of educational interventions, and what might explain any observed pattern in the data?

\section{DATA AND METHOD}

This study draws on data from a first-year calculus course in 2014/2015 and 2018/2019, respectively. Identical surveys were distributed online once grades were received, prompting students to report on achieved mathematics and physics grades in High School and calculus grades at the university. This enabled correlation analysis of grades and survey item responses on a 1-9 Likert scale. Considerable interest is attached to the study of change, particularly in view of recent interventions aimed to improve learning (Langaas, Buan, Skauvold, \& Thaule, 2017; Rønning, Buan, Langaas, \& Thaule, 2017; Thaule, Buan, Rønning, \& Langaas, 2017). Since only a fraction of the students responded, representativeness was determined by comparing grade distributions for the entire cohorts with those in the survey samples.

\section{INTERVENTIONS AND RESULTS}

From 2013 through 2015 a range of educational measures were offered. Importantly, one-way lectures were partially replaced by interactive learning sessions, and a digital platform named Maple TA enabled the inclusion of diverse sets of problems. Furthermore, digital thematic pages and videos were offered as well as better qualified staff aiming to tailor responses to individual needs. Given the range of measures aimed at improved learning, changes in terms of attitudes and study behaviours were expected. Student satisfaction studies witnessed positive sentiments; however, such studies have little to offer when it comes to evidence of attitudes and behaviours in relation to academic achievement.

The analysis confirms strong correlations between mathematics and physics grades in High School and calculus grades at the university. Achievement patterns reoccur as if educational interventions yielded marginal or no impacts. By correlating grades with survey item responses, it appears that academically successful students exhibited different practices compared with those at the opposite end of the grading scale. High grades correlated with an ability to keep pace with workload and progression, while low achievers typically attributed own misfortune to external factors, such as flawed grading procedures. Academic success boosted self-confidence, while the absence of positive experience minimized selfrewarding mechanisms. Even tasks with a great potential for learning were subverted into opportunistic approaches and a search for "correct" answers, thus giving a shine of learning; however, shallow and short lived. A summary of the most striking correlations is gathered in the matrix underneath.

\begin{tabular}{|l|l|}
\hline $\begin{array}{l}\text { The better the grades in mathematics and physics from } \\
\text { High School, the better the grades in calculus }\end{array}$ & $\begin{array}{l}\text { The poorer the grades in mathematics and physics } \\
\text { from High School, the poorer the grades in calculus }\end{array}$ \\
\hline And, the better the grades in calculus ... & And, the poorer the grades in calculus ... \\
\hline$\ldots$ the fairer students deemed it to be. & $\ldots$ the more unfair students deemed it to be. \\
\hline$\ldots$ the greater the effort and intention to understand. & $\ldots$ the lesser the effort and intention to understand. \\
\hline$\ldots$ the more active and hardworking students. & $\ldots$ the more passive and struggling students. \\
\hline$\ldots$ the stronger the perceptions of valid grading. & $\ldots$ the weaker the perceptions of valid grading. \\
\hline$\ldots$ the better ability to keep pace with progression. & $\ldots$ the less ability to keep pace with progression. \\
\hline
\end{tabular}

\section{DISCUSSION}

Only minor differences in attitudes and behaviours were observed from one case to the other, and efforts aimed at the opposite did not seem to make a difference. This was contrasted by favorable responses on student satisfaction studies of teaching; however, such evidence has little to offer when it comes to 
understanding causal links in learning environments. It is still a widely held belief that teachers can impact approaches to learning (Case, 2015); however, this view has been criticized by other researchers "... a theory with this degree of simplicity cannot possibly account for the complexity of teaching ..." (Case, 2015, p. 627). The observation that interventions largely failed to make changes may indicate the presence of other forceful variables acting to maintain status quo. One researcher put it this way: "Actions that are not directly and systematically related to what is relevant in the action scene/context are destined to fail at producing and sustaining the desired change (Simmons \& Gregory, 2003).

By examining the educational interventions, most of them can be categorized as intentional rather than grounded. Measures were located within the bounds of one single course without attention to potential impacts caused by the larger social and professional environments. As a guide for change, Simmons \& Gregory (2003) argue in favor of an explanatory theory as the first step. However, given the complexity of teaching-learning environments, attempts at establishing such a theory may be both demanding and time consuming. Simmons \& Gregory (2003) still argue that any change effort should earn its way supported by data. In calculus, educational interventions rather seemed to be rooted in the belief that extended and more easy access to learning resources would make a difference.

Any educational interventions will by necessity be underpinned by notions of change. While Grounded Action outlines step-by-step procedures based on an explanatory theory of change, Critical Realism (GA) offers a more comprehensive philosophical framework of reality. A distinction is made between what we know (epistemology) and what is real (ontology), and proponents of this philosophy assume the existence of a reality beyond our senses, ultimately consisting of three layers of which only the empirical level can be observed and experienced (Archer, 2010). At the actual level, metaphorically located underneath the empirical level, events occur whether observed or not; however, impacted by properties and structures in the real level causing events to happen (Fletcher, 2017).

A "property" refers to the aggregate consequences of prior action and "structures" to the arrangement of and relations between properties (Archer, 2010, p. 239). Structural conditioning predates attempts at transformations and continue to exert a constraint on such interventions (Archer, 2010, p. 232). Applied to our study, students were under the influence of structures established prior to university studies, which may also account for correlations of achievements in High School and in calculus. While academically successful students continued to be so at the university, their less successful peers maintained preexisting attitudes and behaviours. Archer (2010) asserts this may be ascribed to the application of diverse human reward systems: Extrinsic motivation is driven by external rewards such as just achieving a pass grade, while intrinsic motivation promotes learning characterized by joy and satisfaction of new insights.

Workload and progression of parallel courses in the first semester, may have acted as reproductive powers inhibiting structural elaboration to produce desired changes. Change does not occur in a vacuum, and change agents must consider productive as well as counterproductive forces, requiring insights into environments beyond one single course. A starting point would be to identify the nature and scope of reward systems, with an emphasis on structural elaboration to promote more of intrinsic motivation.

\section{CONCLUSION}

This study explored whether attitudes and behaviours among first-year calculus students changed as a result of educational interventions. Despite sustained efforts, attitudes and behaviours remained largely the same. This is explained by Critical Realism as a philosophical framework with its focus on driving forces beyond observable events, such as histories of learning, including the application of internal and external reward systems. While this approach may not account for the full truth, the application of a valid explanatory framework of change appears as essential to inform prospective future projects.

\section{REFERENCES}

[1] Archer, M. S, (2010), Morphogenesis versus structuration: on combining structure and action, British Journal of Sociology, Vol. 61, pp. 225-252.

[2] Case, J. F. (2015). Emergent interactions: rethinking the relationship between teaching and learning, Teaching in Higher Education, Vol. 20, No. 6, pp. 625-636. 
[3] Fletcher, A. J. (2017), Applying critical realism in qualitative research: methodology meets method, International Journal of Social Research Methodology, Vol. 20, No. 2, pp. 181-194.

[4] Heid, M. K. (1988), Resequencing Skills and Concepts in Applied Calculus Using the Computer as a Tool, Journal for Research in Mathematics Education, Vol. 19, No. 1, pp. 3-25.

[5] Langaas, M., Buan, A. B., Skauvold, J., \& Thaule, M. (2017), Læringsressurser i grunnutdanningen i matematikk - kvalitet, tilgjengelighet og differensiering. Laring om laring, NTNU, Vol 1, pp.136-143.

[6] Rønning, F., Buan, A. B., Langaas, M., \& Thaule, M. (2017), Bruk av digitale øvinger i grunnutdanningen i matematikk. Læring om læring: Laring om laering, NTNU, Vol. 1, pp. 113-119.

[7] Simmons, O., \& Gregory, T. (2003), Grounded Action: Achieving Optimal and Sustainable Change. Forum: Qualitative Social Research, Vol. 4, No. 3.

[8] Snyder, B. R. (1971), The hidden curriculum, New York: Knopf.

[9] Thaule, M., Buan, A. B., Rønning, F., \& Langaas, M. (2017), Alternativ forelesningsstruktur i grunnutdanningen i matematikk. Læring om læring: Laring om laering, NTNU, Vol 1, pp. 120-128.

[10] White, P., \& Mitchelmore, M. (1996), Conceptual Knowledge in Introductory Calculus, Journal for Research in Mathematics Education, Vol. 27, No. 1, pp. 79-95. 